\title{
DIVE RESORT MAPPING AND NETWORK ANALYSIS: WATER RESOURCES MANAGEMENT IN PEMUTERAN COASTAL AREA, BALI - INDONESIA
}

\author{
Muh Aris MARFAI, (D), Benarifo AHMADA ${ }^{1}$, Bachtiar MUTAQIN ${ }^{1,2}$ (D), Rainey WINDAYATI
}

DOI: 10.21163/GT_2020.152.11

\begin{abstract}
:
As the world's best tourist destination in 2017 according to the world's largest travel site, Trip Advisor, Bali offers several tourism activities, including scuba diving. One of the famous dive sites is in the north of Bali, specifically Pemuteran Village. As a result, tourism activities contributed to water shortages in 2009 and 2013, partly because they used up to 65\% of the available water supply. This study sought to determine water use and management by the dive resorts in Pemuteran Village and analyze their work connections in supporting tourism business activities, particularly those related to scuba diving. The technical approach used in this research, namely the integration of the mapping and network analysis to measure the water management in the local context, is considered as the appropriate method where the human geographical interview and survey meets with the technical geography of network analysis and mapping. Interviews with dive resort owners and managers in July 2019 produced information on 1) annual water use, 2) efforts and policies related to water use management, and 3) cooperation between dive resorts in Pemuteran Village as an attempt to create sustainable tourism. The results showed that all dive resorts in the village used 30,202,375 liters of water per year and that each of them had internally implemented several strategies to conserve more water. However, based on the technical approach of the Gephi program, the sociogram of the network is currently shown the weak collaboration or agreement between dive resorts on this front, which potentially threatens the sustainability of tourism in Pemuteran Village and affects the income of the local people.
\end{abstract}

Key-words: Tourism, Water use, Social network, Scarcity, Bali, Indonesia.

\section{INTRODUCTION}

Indonesia is one of the largest archipelagic countries in the world, with a water area of 6,315,222 $\mathrm{km}^{2}$ and coasts stretching along 99,093 km (Mutaqin, 2017). This condition makes Indonesia had numerous tourist destinations as well as attract numerous tourists, including more than 16 million foreigners, to explore those places (Indonesian Ministry of Tourism and Creative Economy, 2020). Tourism activities in Indonesia began in the New Order era (1966-1998), and it is among the highest growing sectors in Indonesia (Agustan and Kausar, 2019). Since 2017, Bali, an island in Indonesia, has become the world's best tourist destination according to TripAdvisor, the world's largest travel site (Lewis \& Lewis, 2009; TripAdvisor, 2018; Mutaqin et al., 2020). According to Statistics Indonesia, in 2018, I Gusti Ngurah Rai International Airport in Denpasar, Bali, is the most visited gateway by international tourists arriving in Indonesia.

One of the favorite dive sites in Bali is Menjangan Island, part of the West Bali National Park (TNBB) (Ernawati, 2011). In the national park area, lodging activities or hotel constructions are prohibited. As a result, Pemuteran Village, situated $18 \mathrm{~km}$ or 1 hour by speedboat from the national park (Fig. 1), has been developed into a lodging center or resorts for tourists planning to visit Menjangan Island. Pemuteran Village is geographically located at the coordinates $8^{\circ} 13^{\prime} 00^{\prime \prime}$ $8^{\circ} 07^{\prime} 30^{\prime \prime S}$ and $114^{\circ} 40^{\prime} 30^{\prime \prime}-114^{\circ} 37^{\prime} 00^{\prime \prime} \mathrm{E}$ and has an area of $32.86 \mathrm{~km}^{2}$ (see Fig. 1).

\footnotetext{
${ }^{1}$ Universitas Gadjah Mada, Faculty of Geography, Coastal and Watershed Research Group, 55281

Yogyakarta,Indonesia, arismarfai@ugm.ac.id, benarifo.ahmada@mail.ugm.ac.id, mutaqin@ugm.ac.id, rainey.windayati@mail.ugm.ac.id

${ }^{2}$ Université Paris 1 Panthéon Sorbonne, Laboratoire de Géographie Physique UMR 8591, 92190 Paris, France, mutaqin@ugm.ac.id
} 


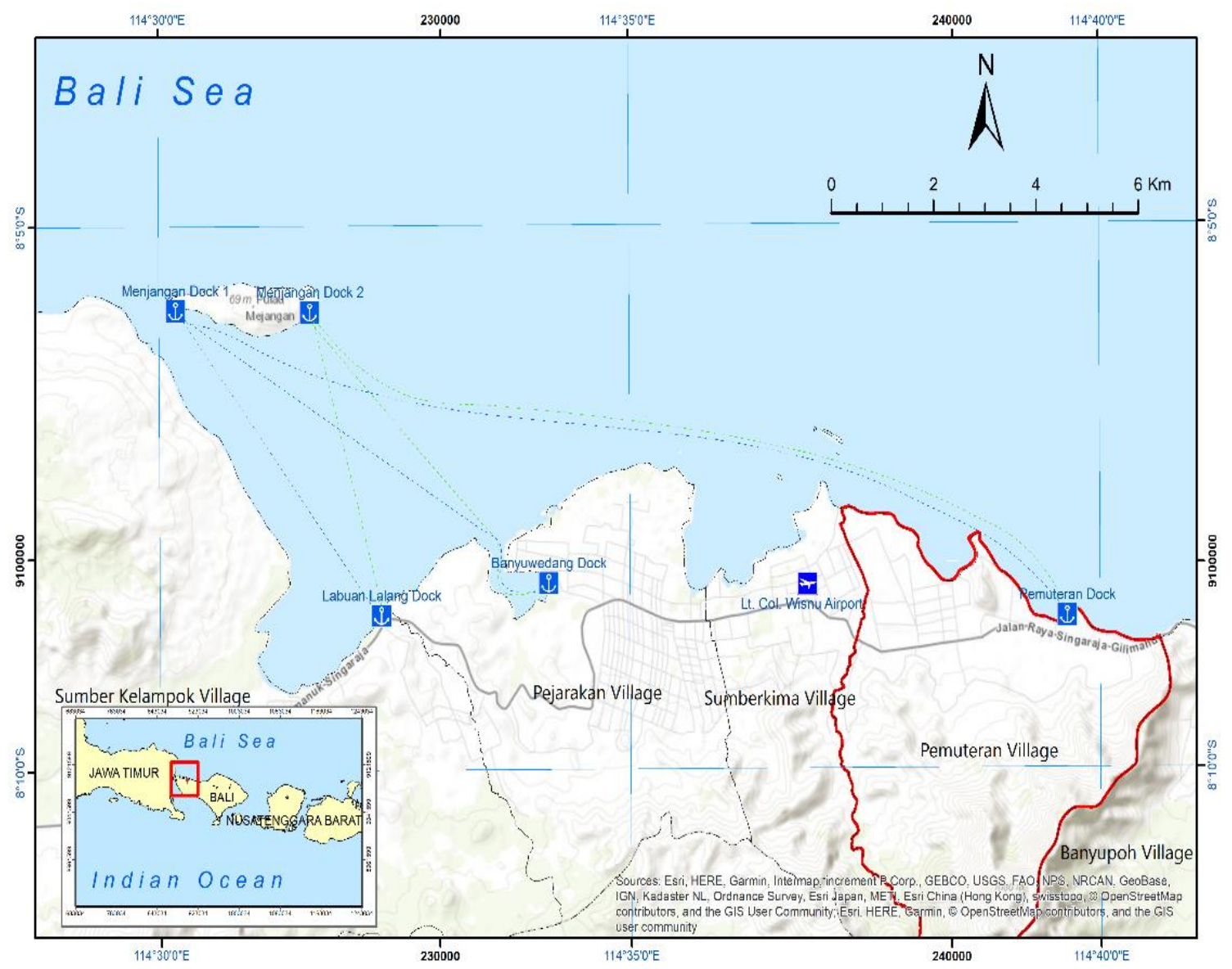

Fig. 1. Map of the locations of Pemuteran Village and Menjangan Island.

In 2017 , there were 44 hotels in this village, with 1,158 people engaging in tourism to accommodate 27,018 tourists (Statistics Indonesia, 2018). Aside from Pemuteran Beach, tourists can cross Labuhan Lalang in Sumber Klampok Village to reach Menjangan Island in 25-45 minutes.

Water resources are a vital asset in the tourism industry and tourism activities that have long been part of the culture of Bali abstract nearly $65 \%$ of groundwater supplies (Gössling et al., 2012; Picard, 1996; Cole, 2012). Consequently, the industry can be less environmentally friendly as it potentially leads to water shortages (Dwianika et al., 2020), as occurred in Pemuteran Village in 2009 and 2013. In Bali, the philosophy of Tri Hita Karana perceives water as a symbol of harmony between humans and nature (Sunarta \& As-syakur, 2015; Windia \& Dewi, 2011). This study explores the water use and management strategies adopted by every dive resort in Pemuteran Village and compares this information with the strategic directives issued by the Agency for the Assessment and Application of Technology (BPPT).

In order to understand the water use and management strategy, every dive resort is mapped and exploited in the network analysis. This approach is considered as technical geography, by mapping and analyzing of the geographical object to support the current and future spatial decision-making processes aimed at preserving the sustainable development of earth (Ormeling 2009). This technical approach by the integration of the conventional mapping of the social/human geographical object and network analysis (a technical geographic method) represents a significant advance in knowledge. Dive resorts are hotels or places of lodging that provide marine tourism services, including scuba 
diving. Due to their ubiquity in the village, understanding their role in local water resource conservation is imperative.

This study also reveals how dive resorts collaborate to organize marine tourism in the village. To measure the intensiveness of the collaboration of dive resorts, the sociogram from the Gephi program has been utilized in this research. It offers information on whether the collaboration is limited to business matters such as cooperation under the pretext of sharing costs, news, knowledge, and skills, or it extends to collective water resource management (Jesus \& Franco, 2016; Krželj-Č́olović et al., 2016).

\section{METHODS}

This study collected four types of data: (1) the amount of water used by dive resorts in Pemuteran annually, (2) the strategies adopted by each dive resort in Pemuteran to manage its water resources, (3) networks between dive resorts to maintain their activities, and (4) the respondent's view of the water crisis in Bali, especially in Pemuteran. Also, it used two criteria for dive resorts. First, the dive resorts are defined as lodging businesses that provide scuba diving experiences for their guests who have or have not been certified by diving affiliates such as PADI, SSI, and SDI. Second, if a resort or homestay has permanent cooperation with a dive center, then it is excluded from this research. By combining these criteria with a snowball sampling technique, this study obtained ten (10) dive resorts for the object of analysis.

The required data were collected by structured interviews using a questionnaire and began with an observation phase to find suitable dive resorts. After two days of observation at the end of June, the next step was an interview for the next ten days and a census of the dive resorts in Pemuteran Village according to the predefined criteria. Structured interviews with key informants, owners, managers, or front desk employees aimed to acquire information on the identity of the dive resort and its total water consumption per year. Identity and water needs were approached using several factors, namely: 1) monthly water bills, 2) the number of guests per year, 3) the number of employees working at the dive resort, and 4) facilities and services (i.e., swimming pools, fish ponds, laundry services, spa, and swimming pools to clean diving equipment like masks, snorkels, fins, wetsuits, and scuba sets). If the dive resort did not keep any groundwater bills, then total water consumption was estimated from the number of guests and employees and through questions on the frequency of lawn watering and room cleaning.

Based on the assumption of water consumption per capita, the number of guests was multiplied by $250 \mathrm{~L} /$ day (SNI, 2005), while the number of employees was multiplied by $30 \mathrm{~L}$ for the entire working hours (Gössling et al., 2015). The interviews also identified the strategies that the dive resorts adopted to manage water resources and the type of networks and connections they established with each other. These data included the current and future models of cooperation to sustain the business circumstances in Pemuteran and, at the same time, preserve the environment.

Afterward, data on water usage of each dive resort were summed. Meanwhile, details on strategies to reduce water consumption were analyzed descriptively and compared with water-saving efforts that had been established in other regions (literature reviews). Finally, information on dive resort cooperation was transformed into visual illustrations. Adequate and appropriate visual presentation of the geographical object is crucial to give an understanding of the entire spatial analysis and connectivity of the object studied (Haidu, 2016; Ruda, 2016; Bobková and Holešinská, 2017). Visual illustration has been done by utilizing a technical approach using the Gephi program. Gephi is an open-source computer program that helps researchers to uncover designs and patterns, highlight exceptions instinctively, and tells stories with their data. Gephi combines built-in functionalities and adaptable engineering to visualize, analyze, and manipulate all sorts of networks and their data properties (Bastian et al., 2009; Jacomy et al., 2014).

Gephi program, in combination with the spatial analysis, is beneficial and considered as an innovative way to do the analysis of the geographical phenomenon and to measure the intensiveness of the collaboration among actors in the study area. This presentation was integrated with spatial data, 
i.e., coordinate points, to produce a comprehensive map containing water consumption and dive resort networks in Pemuteran Village.

The technical character is reflected on the point coordinate mapping through survey and interview as well as on the appropriate and adequate presentation of network analysis by sociogram and Gephi program.

\section{RESULTS AND DISCUSSIONS}

In the illustration on water usage and dive resort's collaborative networks, the ten dive resorts were represented by numbers, from 1 to 10 , to preserve anonymity.

\subsection{Total water usage}

The overall water usage by the dive resorts in Pemuteran Village was 30,202,375 L/year. This figure was obtained through interviews with dive resort managers and owners. Only three of the ten dive resorts kept proof of paid monthly well water bills. As for the other seven dive resorts, the water consumption rate was approached from water use per capita (guests and employees), facilities and maintenance, cleanliness, and irrigation. The amount of water consumption is presented in Table $\mathbf{1}$.

Table 1.

Total groundwater use by the dive resorts in Pemuteran, Bali.

\begin{tabular}{|c|r|}
\hline Dive Resorts & Groundwater consumption (L/year) \\
\hline 1 & 159,000 \\
\hline 2 & 511,345 \\
\hline 3 & 567,357 \\
\hline 4 & 573,237 \\
\hline 5 & $1.149,524$ \\
\hline 6 & $1,438,000$ \\
\hline 7 & $2,068,000$ \\
\hline 8 & $2,349,494$ \\
\hline 9 & $10,494,418$ \\
\hline 10 & $10,892,000$ \\
\hline Total & $\mathbf{3 0 , 2 0 2 , 3 7 5}$ \\
\hline
\end{tabular}

Compared with other dive resorts, the ones in Pemuteran Village used a smaller amount of water in 2019 (30,202,375 L/year). For instance, Resort A in Langkawi and Resort B in Miri withdraw up to $63,875,000 \mathrm{~L}$ and $118,625,000 \mathrm{~L}$ of water per year (Tang, 2012). These resorts have 117 and 220 rooms, respectively, which are more than the dive resorts in Pemuteran. The number of rooms is directly proportional to the number of potential guests and the amount of water these guests need. In Pemuteran Village, Dive Resort 9 had the highest number of rooms, namely 80, and the annual water consumption was $10,494,418 \mathrm{~L}$. The total water usage of all dive resorts in the study area is still lower than hotels or resorts that do not offer diving services, such as in Malaysia (182,500,000 L/year), Makassar (259,875,072 L/year), and Zanzibar (316,765,250 L/year) (Gössling, 2001; Tang, 2012; Ridwan, 2012). Other than the number of rooms and visitors, differences in water requirements depend on the resort or hotel facilities, e.g., swimming pools, laundry services, cleaning and floor maintenance (i.e., mopping), fish ponds, plant maintenance, place of worship, and food preparation activities in the restaurant (i.e., dishwashing and cooking). Furthermore, seasons and the size and type of resort also determine the water demand (Chan et al., 2009).

\subsection{Water-saving strategy in the dive resorts}

Dive resorts are a form of business that combines diving tourism with a place of lodging. Despite the high precipitation rate in Indonesia, it is only natural for each lodging business entity to implement 
a water-saving strategy to sustain water availability for domestic use and, consequently, preserve the supply and demand flow of the guests visiting Pemuteran Village (Becken, 2014).

Besides, water conservation is covered in the Sustainable Development Goals, Goal 6: Clean water and sanitation, issued by the United Nations (UN) in early 2016 (https://www.un.org/sustainabledevelopment/). The results showed that seven out of the ten dive resorts had implemented efforts to conserve groundwater use, while the other three did not have clear water-saving strategies.

For the respondents, be it employees, managers, or hotel owners, water-saving means reducing not only groundwater bills but also electricity expenses. The water pipelines managed by the regional government-owned water company, PDAM, does not reach Pemuteran Village; therefore, the dive resorts, as well as other homestays, have to use electric pumps to extract water from bore wells. The withdrawal of a higher amount of water requires a higher voltage for the pump to work. Dive Resorts 5 and 9 have official licenses from PADI, an international diving affiliate, as PADI five-star dive resorts. Also, Dive Resort 5 has been named as one of the 16 best eco-resorts in the Asia Pacific by Scuba Diver magazine because it has a recycling system for wastewater from baths.

Based on the interview with a respondent from Dive Resort 5, the wastewater from bathing flows from each room in this resort to the recycling system and is reused to water the plants. With this design, the wastewater recycling system is similar to that of Frangipani Langkawi Resort and Spa in Malaysia (Kasim et al., 2014). Frangipani recycles by discharging treated wastewater to the wetland, and this process is assisted by planting aquatic plants in this ecosystem. Dive Resort 5 does not use aquatic plants to recycle wastewater, but it relies on a liquid waste-treating machine used by the Agency for the Assessment and Application of Technology (BPPT) (Yudo, 2018). It also sorts towels, linens, and pillowcases for the guests by choosing only ones with thin material that requires less time and water for washing and drying. This strategy has not been exposed in previous studies and is thereby a new and simple innovation.

Only five dive resorts provide a swimming pool for their guests, namely Dive Resorts 1, 2, 4, 8, and 9. The first four claimed to have never changed the water in the swimming pool since it was first operated. However, instead, they added chemicals such as Poly Aluminum Chloride (PAC), Soda Ash, and Copper Sulphate to maintain the quality of the swimming pool water. The five dive resorts have also installed water recycling equipment for the swimming pools. This water-saving method for the swimming pool is also found in the resorts in Thessaloniki, Greece, that use chemicals $(\mathrm{Cl})$ as a disinfectant and water re-installation equipment to keep the pool water clean (Marinopoulos and Katsifarakis, 2017). Furthermore, Dive Resorts 2, 3, 4, and 9 have built fish ponds on their properties to improve their decoration, and three of them have installed water purification equipment to drain water from the fish ponds every 1-2 months. At the same time, Dive Resort 6 has constructed some infiltration wells around the property to conserve water. This application follows the water-saving strategy adopted by the BPPT building (Yudo, 2018), which aims to accommodate overland flow or surface runoff in case of heavy rain and, therefore, decrease groundwater exploitation.

Most dive resorts have a technical water-saving strategy. Some have different ways of conserving drinking water, but this is not necessarily followed by an increase in groundwater use by the dive resorts. For instance, instead of providing water in disposable bottles, these resorts serve drinking water in a gallon. According to the respondent, bottled water is a waste of water because, habitually, many people do not drink the entire content. When no longer needed, the bottle is thrown away with the remaining water in it. If calculated cumulatively, there will be much water wasted from this type of package. Meanwhile, water gallons will not be replaced until they are empty, and the used ones can be refilled. Aside from adding up the volume of plastic waste, bottled water is believed to increase the company's operating budget. For these reasons, the dive resorts choose to provide water gallons as part of their amenities. A key informant from Dive Resort 8 admitted that the resort was committed to the plastic reduction movement. Table 2 summarizes the identified strategies and efforts of each dive resort to reduce groundwater exploitation.

Interviews with 14 respondents found out their opinion on water scarcity in Bali, including water deficit in 2009 and 2013 (Sunarta and As-Syakur, 2015) (Fig. 2). Respondents who were residents of 
the Buleleng Regency were mostly unaware that the regency and the entire Bali were experiencing water crises.

In contrast, respondents who were foreign nationals claimed that they knew about these adverse events because their curiosity about the local condition before arriving in Bali to work at the dive resorts had led them to this information and the fact that the tourism industry used up to $65 \%$ of the available water in Bali.

Table 2.

The water-saving strategies adopted by the dive resorts in Pemuteran, Bali.

\begin{tabular}{|r|l|c|r|}
\hline No & \multicolumn{1}{|c|}{ Strategies } & $\begin{array}{c}\text { Number } \\
\text { of Users }\end{array}$ & $\begin{array}{c}\text { Dive } \\
\text { Resorts }\end{array}$ \\
\hline 1 & $\begin{array}{l}\text { Applying recycling technology for toilet wastewater and reusing the treated } \\
\text { water for the plants }\end{array}$ & 1 & 5 \\
\hline 2 & Adding chemical ingredients and equipment to clear the swimming pool water & 4 & $1,2,4,8$ \\
\hline 3 & Installing a water purifier for the fish ponds & 1 & 2 \\
\hline 4 & Constructing infiltration wells & 1 & 6 \\
\hline 5 & Providing water in gallons instead of plastic bottles & 1 & 8 \\
\hline 6 & Using sprinklers to water the plants & 4 & $5,7,8,9$ \\
\hline 7 & Reusing the wastewater from dive-gear washing to water the plants & 2 & 4,3 \\
\hline 8 & Using household appliances made of thin materials & 1 & 5 \\
\hline
\end{tabular}

About $69 \%$ of the respondents reported no difficulty in accessing water, while the other $31 \%$ claimed that access to clean and fresh water had been challenging. For Dive Resort 7, clean water was difficult to access, and the deep wells often completely dried despite their $15 \mathrm{~m}$ depth. This situation is potential because the dive resort is not located in a shallow groundwater zone. Besides, Dive Resort 7 is located on the west and adjacent to Sumberkima Village. Based on the interview results, this location suffered water shortages even though the local government, through the water company PDAM, had facilitated the residents of Sumberkima Village with access to clean water.

In general, the respondents showed awareness and positive attitude toward the water problem in Pemuteran and, under this circumstance, had applied various attempts to save water. The government can use this finding as a reference to promote water conservation programs. Most importantly, all respondents expressed their willingness to support these plans should the government decide to actualize them. Public opinion of the criticality of water in Pemuteran Village is presented in Table 3.

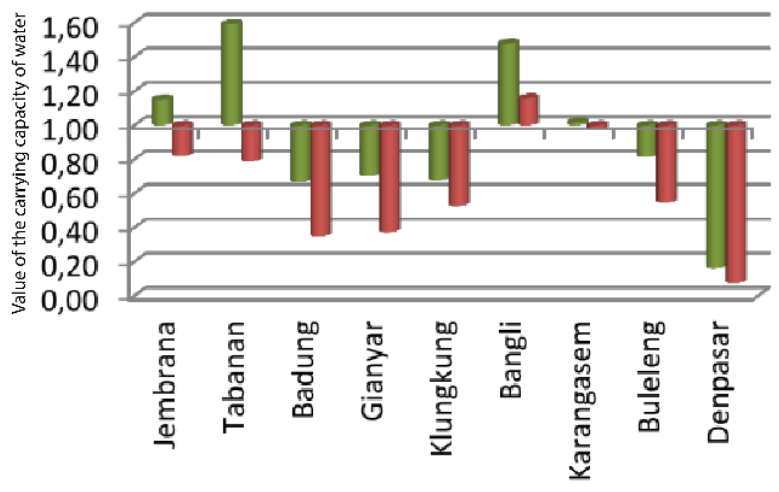

Fig. 2. Water balance diagram of Bali Province.

(Source: Sunarta and As-Syakur, 2015). 
Table 3.

The response of informants to the water scarcity issue in Pemuteran, Bali (in \%).

\begin{tabular}{|c|l|r|r|}
\hline No & \multicolumn{1}{|c|}{ Questions } & Yes & \multicolumn{1}{c|}{ No } \\
\hline 1 & Do you know that Bali is projected to suffer water shortages? & $46 \%$ & $54 \%$ \\
\hline 2 & Do you know that Buleleng Regency is experiencing water shortages? & $15 \%$ & $85 \%$ \\
\hline 3 & Do you encounter difficulties in accessing water? & $31 \%$ & $69 \%$ \\
\hline 4 & Do you care about the water problems in Pemuteran Village? & $100 \%$ & $0 \%$ \\
\hline 5 & Have you tried any strategies to save water? & $100 \%$ & $0 \%$ \\
\hline 6 & Do you know that the tourism industry uses up to 65\% of available water in Bali? & $69 \%$ & $31 \%$ \\
\hline 7 & $\begin{array}{l}\text { Are you willing to support any efforts that the government and community } \\
\text { perform to save water? }\end{array}$ & $100 \%$ & $0 \%$ \\
\hline
\end{tabular}

\subsection{Network analysis between dive resorts}

The network established among the dive resorts was analyzed using a sociogram, which was created in Gephi application with ten nodes (dive resorts) and ten edges. Here the sociogram is considered as a useful method to understand the network of collaboration among the actors. The sociogram is a result of the technical approach in the analysis of the Gephi program. The size of each node is the amount of water consumption per year, while the color represents the presence or absence of water-saving strategies adopted by the dive resort. The edge is a line that connects the nodes, depicting the collaboration between the dive resorts. There are two types of edges, namely the blue line with arrows for cooperation in coral reef protection called Pemuteran Environmental Trust (PET) and the black line for operational activities. Dive Resort 5 initiated PET by inviting all diving enthusiasts and nearly all dive resorts and dive centers in the village. According to the respondent representing Dive Resort 5, many parties have participated in PET activities. Aside from private resorts, several dive resorts that are still under development (only about two years old) are not included in the PET network. An example includes Dive Resort 6, which is a private one that partners with the dive center in Denpasar and, therefore, only accepts guests from it. Based on the statement of respondents from Dive Resort 9-which is one of the Pemuteran Local Dive Center (PLDC) groups, PET activities take place every week with a rotating work system. For example, Dive Resort $\mathrm{A}$ is in charge of carrying out PET activities in the first week, and Dive Resort B is responsible for the second week, then Dive Center A in the next week, and so on. The sociogram is shown in Fig. 3 and is placed over the map of the study area in Fig. 4.

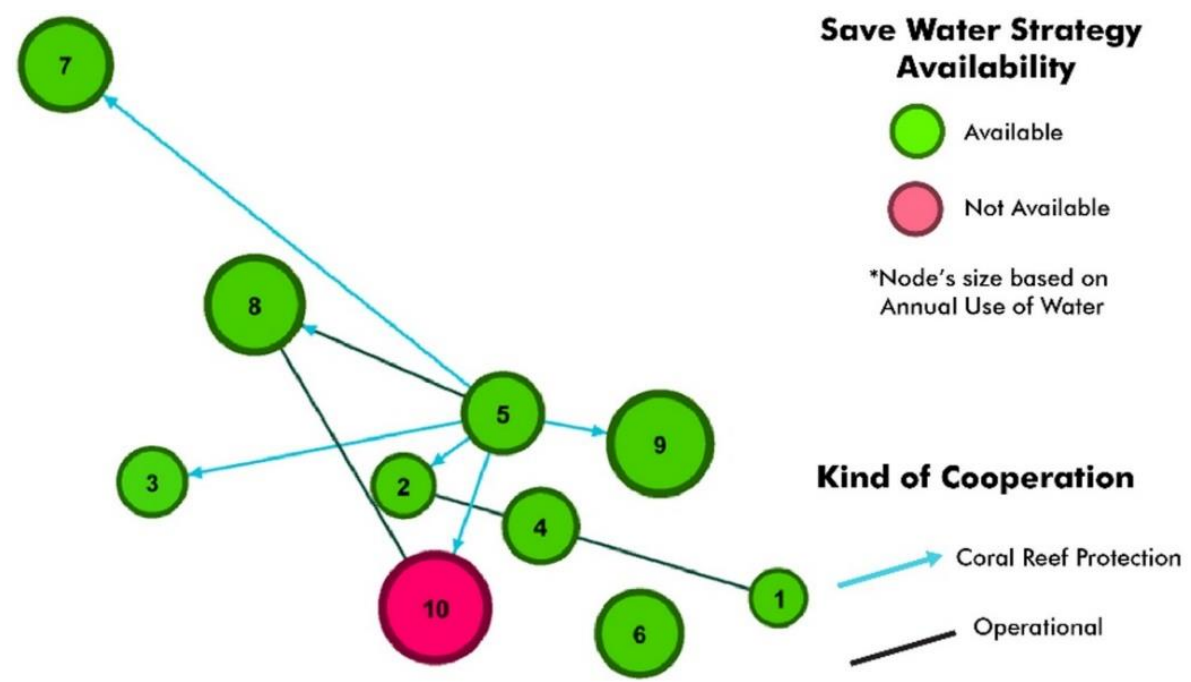

Fig. 3. The sociogram of the dive resorts in Pemuteran, Bali. The availability of water-saving strategies is shown in green and red colors. Node's size is based on annual water use. 
Operational activities seek to maintain a healthy ecosystem for business competition and a place for communication between dive resorts and dive centers, which are represented by divemasters employed at one of the companies or working odd jobs (freelance dive masters). The conversation merely takes place in an online group chat via WhatsApp application. It mostly discusses requests on a divemaster or dive instructor and equipment and boat sharing to reduce the operational costs of a marine tour to Menjangan Island or the dive sites around Pemuteran and Sumberkima. Several respondents mentioned that a few years ago, there was a price agreement in dive tourism service between the companies to prevent damages to the market price (i.e., below price floors or above price ceiling) and interference to the business competition atmosphere. However, several individuals denied this agreement, which indirectly caused it to cease. Until now, there has been no attempt to bring the companies together to discuss the issue.

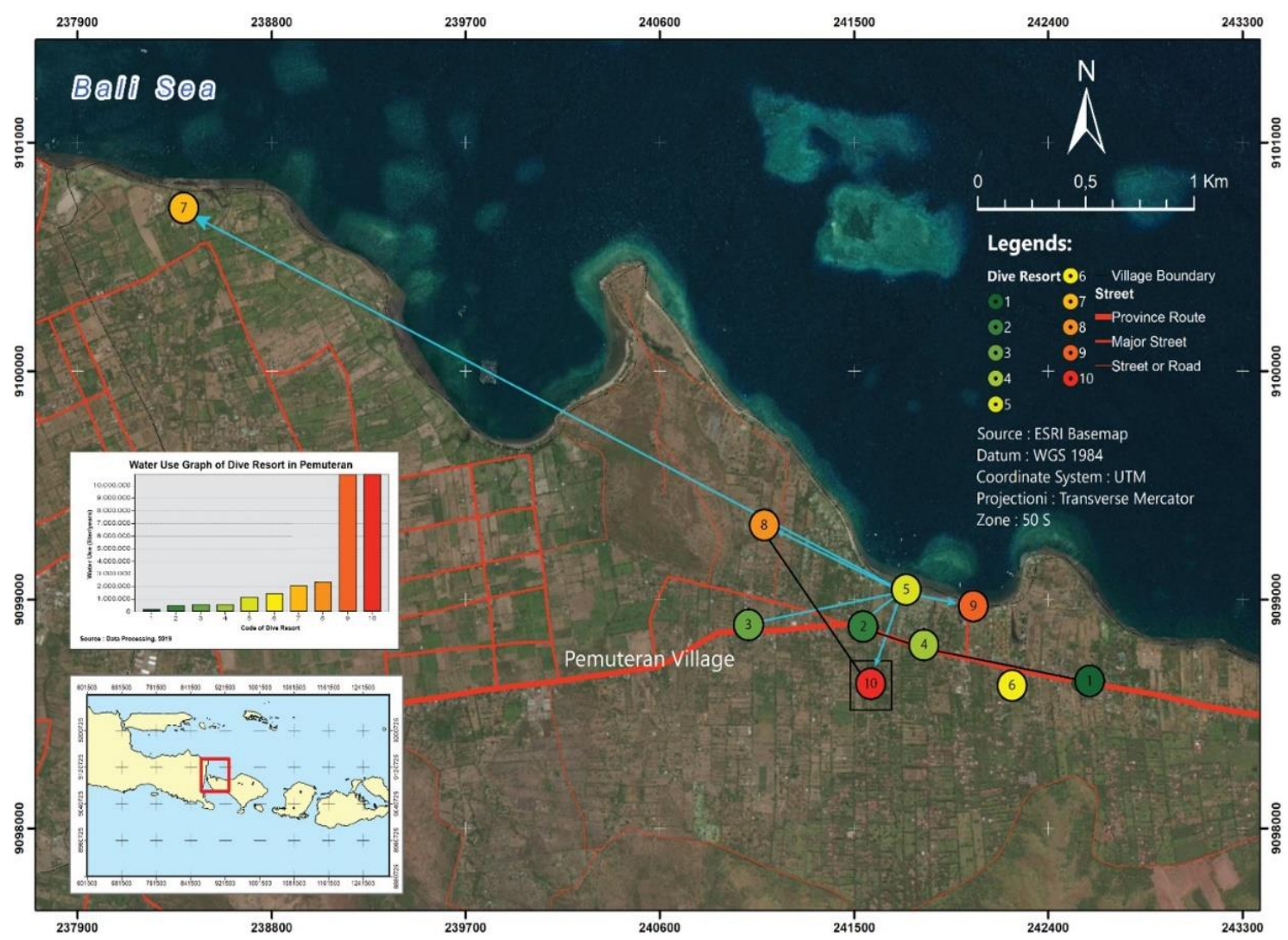

Fig. 4. The sociogram map of the dive resorts in Pemuteran, Bali.

Every dive resort has its connections in operational aspects that stem from personal kinship, intercompany working contracts, and geographical proximity. The black lines or edges illustrate the statement of each respondent on intercompany connections. This connection reflects the cooperation among the dive resorts in several situations: (1) lack of equipment, requiring the company to rent one from other dive resorts, (2) unavailable divemaster/instructor at the dive resort for the marine tour, forcing the company to rent one from another dive resort, and (3) the number of guests do not meet the operational costs for the tour, requiring the company to coordinate with other dive resorts, share a boat, and entrust their guests at an agreed price. These connections only illustrate ones among dive resorts, but not between dive resort, dive center, and other dive shops. 
The work connections depicted in Fig. $\mathbf{4}$ are not as complicated as the ones developing on Gili Trawangan Island. Parteleow and Nelson (2020) include the work connections between the dive center and dive shops, resulting in a significantly higher number of nodes and edges. In 1992, a dive center was established on Gili Trawangan, and this year marks the beginning of the dive tourism on the island, which is eight years older than the first official dive tourism activity in Pemuteran Village (2000). In contrast to Parteleow and Nelson (2020), this study highlights the work connections among the dive resorts, providing more enriched information.

\section{CONCLUSIONS}

All dive resorts in Pemuteran Village need 30,202,375 liters of water per year to provide the best services to their guests. In response to potential water scarcity in Bali, each dive resort manages water by implementing specific strategies to conserve more groundwater. Although there is no mutual agreement or specific regulation from the government of Pemuteran Village, each business actor behind the dive resorts is aware of the importance of minimizing groundwater consumption and even willing to help and support the government in its efforts to save water.

The work connections among the dive resorts in Pemuteran Village are divided into two types of partnerships, namely operational cooperation and collaboration in marine ecosystem conservation. This work is considered as a preliminary project utilizing more interviews and secondary data. However, for future work, a statistical approach and method should be used to reveal the quantitative analysis and to understand the detailed connectivity in every dive resort.

\section{ACKNOWLEDGMENTS}

This research is part of the Indonesia Collaborative Research Program (PPKI - ECODEBUZ) 2019 No. 2052/UN1.P.III/DIT-LIT/LT/2019 and supported by the grant of thesis research 2020. The authors dedicate this article to Prof. Sunarto, as well as Dionisius Prasetyo, who died recently. Furthermore, the authors would like to extend their gratitude to all the members of the Coastal and Watershed Research Group in the Faculty of Geography UGM for their help and moral support during the fieldwork. We also thank anonymous reviewers for their helpful comments on this paper.

\section{R E F E R E N C E S}

Agustan, A. and Kausar, D.R.K. (2019). Towards a Framework for Disaster Risk Reduction in Indonesia's Urban Tourism Industry Based on Spatial Information. Geographia Technica, 14 (Special Issue), 32-38. http://doi.org/10.21163/GT_2019.141.16.

Bastian, M., Heymann, S., Jacomy, M. (2009). Gephi: an open source software for exploring and manipulating networks. International AAAI Conference on Weblogs and Social Media, May 17-20, San Jose, California, North America.

Becken, S. (2014). Water equity - Contrasting tourism water use with that of the local community. Water Resources and Industry, 7-8, 9-22. https://doi.org/10.1016/j.wri.2014.09.002.

Bobková, M. and Holešinská, A. (2017). Networking in a Destination from the Perspective of Virtual Relationships and their Spatial Dimension. Geographia Technica, 12 (2), 10-19. http://doi.org/10.21163/GT_2017.122.02.

Chan, W., Wong, K., \& Lo, J. (2009). Hong Kong hotels' sewage: Environmental cost and saving technique. Journal of Hospitality and Tourism Research, 33 (3), 329-346. https://doi.org/10.1177/1096348009338525. 
Cole, S. (2012). A political ecology of water equity and tourism. A Case Study From Bali. Annals of Tourism Research, 39 (2), 1221-1241. https://doi.org/10.1016/j.annals.2012.01.003.

Dwianika, A., Murwaningsari, E., Suparta W. (2020). Analysis of Water Awareness, Accountability, and Governance to Improve Sustainability of Firm's Performance in Urban Areas. Geographia Technica, 15 (1), 35-42. http://doi.org/10.21163/GT_2020.151.04.

Ernawati, N.M. (2011). Pengaruh Pariwisata Terhadap Kehidupan Sosial Budaya Pesisir Di Kawasan Taman Nasional Bali Barat Dan Taman Wisata Pulau Menjangan. Sabda, 6 (April), Pp. 69-74.

Gössling, S. (2001). The consequences of tourism for sustainable water use on a tropical island: Zanzibar, Tanzania. Journal of Environmental Management, 61 (2), 179-191. https://doi.org/10.1006/jema.2000.0403.

Gössling, S., Peeters, P., Hall, C.M., Ceron, J.P., Dubois, G., Lehmann, L.V., and Scott, D. (2012). Tourism and water use: Supply, demand, and security. An international review. Tourism Management, 33 (1), 1-15. https://doi.org/10.1016/j.tourman.2011.03.015.

Gössling, S., Hall, C.M., and Scott, D. (2015). Tourism and Water. Channel View Publications. 190p.

Haidu, I. (2016). What is Technical Geography. Geographia Technica, 11 (1), 1-5. http://doi.org/10.21163/GT_2016.111.01.

Indonesian Ministry of Tourism and Creative Economy. (2020). Kunjungan Bulanan Wisatawan Mancanegara 2019 vs. 2018. https://www.kemenparekraf.go.id/post/data-kunjungan-wisatawan-mancanegara-bulanantahun-2019. Accessed on 16 March 2020.

Jacomy, M, Venturini, T, Heymann, S, Bastian, M. (2014). ForceAtlas2, a Continuous Graph Layout Algorithm for Handy Network Visualization Designed for the Gephi Software. PLoS ONE 9 (6): e98679. https://doi.org/10.1371/journal.pone.0098679.

Jesus, C., \& Franco, M. (2016). Cooperation networks in tourism: A study of hotels and rural tourism establishments in an inland region of Portugal. Journal of Hospitality and Tourism Management, 29, 165175. https://doi.org/10.1016/j.jhtm.2016.07.005.

Kasim, A., Gursoy, D., Okumus, F., \& Wong, A. (2014). The importance of water management in hotels: a framework for sustainability through innovation, Journal of Sustainable Tourism, 22 (7), 1090-1107. https://doi.org/10.1080/09669582.2013.873444.

Krželj-Čolović, Z., Vrdoljak Raguž, I., Beran, I.M. (2016) Strategic Networking in Hospitality Industry. In: Vrdoljak Raguž I., Podrug N., Jelenc L. (eds) Neostrategic Management. Contributions to Management Science. Springer, Cham. https://doi.org/10.1007/978-3-319-18185-1_3.

Lewis, J., \& Lewis, B. (2009). Bali's silent crisis: Desire, tragedy, and transition. Lanham, USA: Lexington Books. 252p.

Marinopoulos, I.S., \& Katsifarakis, K.L. (2017). Optimization of Energy and Water Management of Swimming Pools. A case study in Thessaloniki, Greece. Procedia Environmental Sciences, 38, 773-780. https://doi.org/10.1016/j.proenv.2017.03.161.

Mutaqin, B.W. (2017). Shoreline changes analysis in Kuwaru coastal area, Yogyakarta, Indonesia: An application of the digital shoreline analysis system (DSAS). International Journal of Sustainable Development and Planning, 12 (7), 1203-1214. https://doi.org/10.2495/SDP-V12-N7-1203-1214.

Mutaqin B.W., Marfai M.A., Helmi M., Rindarjono M.G., Windayati R., Sunarto. (2020). Spatio-temporal Mapping of Ecotourism Activities in Buleleng Conservation Zone: A Methodological Review, IOP Conf. Ser.: Earth Environ. Sci. 451 012095. https://doi.org/10.1088/1755-1315/451/1/012095.

Ormeling, F. (2009). Technical Geography: Core Concepts in the Mapping Sciences. In Sala, M. (ed.) Geography - Volume II. EOLSS Publications, pp. 211-231.

Partelow, S., \& Nelson, K. (2020). Social networks, collective action and the evolution of governance for sustainable tourism on the Gili Islands, Indonesia. Marine Policy. 112. https://doi.org/10.1016/j.marpol.2018.08.004.

Picard, M. (1996). Bali: Cultural tourism and touristic culture. Singapore: Archipelago Press. 231p.

Ridwan, A. (2014). Studi Analisis Kebutuhan Air Sektor Nondomestik Kategori Hotel Di Wilayah Kecamatan Ujung Pandang. Bachelor Thesis. Universitas Hasanuddin, Makassar.

Ruda, A. (2016). Exploring Tourism Possibilities using GIS-Based Spatial Association Methods. Geographia Technica, 11 (2), 87-101. http://doi.org/10.21163/GT_2016.112.09. 
SNI. (2005). Tata Cara Perencanaan Sistem Plambing: SNI 03-7065-2005. Badan Standardisasi Nasional Indonesia. $23 \mathrm{p}$.

Statistics Indonesia. (2018). Statistik Indonesia: Statistical Yearbook of Indonesia 2018. BPS - Statistics Indonesia. 762p.

Sunarta, I.N., \& As-Syakur, A.R. (2015). Study on the Development of Water Crisis in Bali Island in 2009 and 2013. E-Journal of Tourism, 2 (1), 33-42. https://doi.org/https://doi.org/10.24922/eot.v2i1.19441.

Tang, F.E. (2012). A Study of Water Consumption in Two Malaysian Resorts, World Academy of Science, Engineering and Technology, International Journal of Environmental and Ecological Engineering. 6 (8), 506-511.

Tripadvisor. (2019, February 20). Top 25 des destinations-Asie. Retrieved from https://www.tripadvisor.fr/.

Windia, W., \& Dewi, R.K. (2011). Analisis Bisnis Berlandaskan Tri Hita Karana. Denpasar: Udayana University Press. 142p.

Yudo, S. (2018). Upaya Penghematan Air Bersih di Gedung Perkantoran Water Saving Efforts in Offices Building Case Study: Water Saving in BPPT Office Building. Jurnal Teknologi Lingkungan, 19 (1), $97-$ 106. 